\title{
PERSEPSI, KONSUMSI DAN PREFERENSI MINUMAN BERENERGI
}

\author{
(Perception, Consumption and Preferences of Energy Drink) \\ Ratika Putriastuti ${ }^{1}$, Lilik Kustiyah ${ }^{2}$, dan Faisal Anwar ${ }^{2}$ \\ ${ }^{1}$ Alumni Program Studi Gizi Masyarakat dan Sumberdaya Keluarga, Fakultas Pertanian (FAPERTA) IPB
2 Staf Pengajar Departemen Gizi Masyarakat, Fakultas Ekologi Manusia (FEMA), IPB
Telp: 0251-8628304/8621258; Fax: 0251-8625846/8622276
}

\begin{abstract}
ABST RACT
The aims of this research were to study perception, consumption and preferences of energy drink and also to analyze relationship between content of energy and caffeine in energy drink. This research used cross sectional study design and conducted in Solo (Terminal Tirtonadi, Terminal Kartasuro and Palur). The respondent (36 persons) was chosen by convenience sampling. Method used to analyze energy content was bomb calorimeter, while caffeine obstetrical analysis used spectrophotometer. The respondent consumed Extra Joss (44.4\%), Hemaviton Jreng (19.4\%), Kuku Bima Energy (13.9\%, Kratingdaeng $(8.3 \%), M-150(5.6 \%)$, Hemaviton Energy drink $(5.6 \%)$ and the rest Fit Up tablet. Reason of consumption is for stamina. The most important attributes selected by respondent were energy adding and activity supporter benefits. Time of working with consumptions (frequency and sum of consumptions) have significant relationship $(p<0.05)$. Energy content (Kal/g) of Extra J oss was 4 278, Hemaviton J reng 2 599, and Kuku Bima Energy 2 720, then caffeine content $(\mathrm{mg} / \mathrm{kg})$ of samples was 8778,7688 dan 9 252, respectively.
\end{abstract}

Keywords: Perception, Consumption, Preferences, Energy Drink

\section{PENDAHULUAN}

\section{Latar Belakang}

Pangan merupakan kebutuhan utama manusia yang terdiri dari makanan dan minuman. Pangan berfungsi sebagai sumber zat tenaga (energi), zat pengatur dan zat pembangun bagi tubuh. Sekarang masyarakat lebih memilih kepraktisan dalam mengkonsumsi pangan. Hal ini menyebabkan terjadinya perubahan pola konsumsi sehingga menjadi trend baru seiring berubahnya gaya hidup masyarakat.

Pada dasarnya setiap orang memerlukan suplai energi yang cukup untuk dapat melakukan aktivitas sehari-hari. Energi ini dapat diperoleh dari makanan atau suplemen. Sumber makanan penghasil energi adalah karbohidrat, protein dan lemak. Energi tersebut digunakan untuk metabolisme basal (mendukung proses metabolisme dasar tubuh) serta untuk aktivitas fisik (Gaman \& Sherrington 1990). Selain itu, tubuh juga memerlukan protein sebagai zat pembangun dan juga vitamin dan mineral sebagai zat pengatur.

Suplemen memiliki batasan istilah yaitu produk yang digunakan untuk melengkapi kebutuhan zat gizi makanan, mengandung satu atau lebih bahan-bahan sebagai berikut yaitu: vitamin, mineral, asam amino atau bahan lain (berasal dari tumbuhan atau bukan tumbuhan) yang mempunyai nilai gizi dan atau efek fisiologis dalam jumlah konsentrasi serta dalam bentuk konsentrat, metabolit, konstituen, ekstrak atau kombinasi dari bahan-bahan sebelumnya (BPOM, 1996). Beberapa suplemen makanan berperan dalam menyuplai energi dan menjadi salah satu alternatif apabila dari konsumsi pangan tidak mencukupi. Hal ini dapat dilihat dengan banyaknya orang yang lebih suka mengambil cara cepat untuk memperoleh energi dengan minuman berenergi (energy drink). Bahkan, banyak yang mengonsumsi minuman berenergi setiap hari karena beranggapan minuman berenergi sebagai sumber tenaga tambahan yang siap untuk digunakan tubuh untuk melakukan aktivitas dan mengonsumsi multivitamin untuk memperlancar proses metabolisme tubuh.

Minuman berenergi termasuk ke dalam minuman suplemen yang didefinisikan sebagai minuman yang mengandung vitamin, mineral serta stimulan seperti kafein, guarana, taurin, variasi bentuk ginseng, maltodextrin, carnitine, creatine, dan ginkgo biloba (Wikipedia, 2006). Pada produk ini ditambahkan zat-zat tertentu yang dapat meningkatkan energi tubuh. Sumber lainnya yang juga mempengaruhi kecepatan reaksi adalah kandungan zat stimulan seperti kafein dan taurin. Kedua zat ini 
berfungsi untuk memperlancar metabolisme tubuh (Marlinda, 2001).

Pangsa pasar produk minuman berenergi sangat luas dan hal ini dapat dilihat dari pertumbuhan yang spektakuler sejak tahun 1997 yang meliputi orang muda, pelajar, orangorang yang sedang bepergian serta orang yang sedang berolahraga (Wikipedia 2006). Salah satunya adalah supir bis malam yang melakukan aktivitas bepergian jauh sehingga membutuhkan asupan energi yang lebih.

Menurut Sudarisman (1997), rata-rata produksi minuman suplemen 93.2 juta liter/tahun yang terdiri dari dua produsen susu dengan kapasitas 24.2 juta liter/tahun, 14 produsen minuman berenergi dengan kapasitas produksi 10.4 juta liter/tahun dan tujuh produsen minuman isotonik dengan kapasitas produksi 10.4 juta liter/tahun. Bahkan volume produksi salah satu minuman berenergi dapat mencapai rata-rata 70 juta bungkus/bulan (Hidayat, 2002).

Kemajuan industri minuman berenergi ini tentunya tidak lepas dari peranan iklan sebagai media promosi kepada masyarakat. Bahkan iklan-iklan ini sangat gencar di berbagai media atau event tertentu seringkali mengemukakan klaim-klaim produk tersebut. Tidak sedikit masyarakat yang percaya terhadap klaim-klaim serta memiliki persepsi dan preferensi tersendiri mengenai produk tersebut. Ketelitian dalam memilih dan informasi yang cukup tentang produk yang akan kita konsumsi menjadi demikian penting. Berkaitan dengan hal tersebut, penulis tertarik untuk mengkaji lebih lanjut mengenai persepsi, konsumsi dan preferensi minuman berenergi khususnya pada supir bis malam.

\section{$\underline{\text { Tujuan }}$}

Tujuan dari penelitian ini adalah mengidentifikasi persepsi dan preferensi contoh terhadap minuman berenergi, mengidentifikasi kebiasaan konsumsi minuman berenergi contoh, menganalisis hubungan antara karakteristik contoh dengan persepsi, konsumsi dan preferensi, dan menganalisis kandungan energi dan kafein pada minuman berenergi.

\section{METODE PENELITIAN}

\section{Desain, Tempat dan Waktu}

Penelitian mengenai Persepsi, Konsumsi dan Preferensi Minuman Berenergi ini menggunakan desain penelitian Cross Sectional Study.
Penelitian dilakukan di Terminal Bis Solo Jawa Tengah yaitu Terminal Tirtonadi, Kartasura, serta Palur. Pemilihan tempat/lokasi penelitian dilakukan secara purposive dengan pertimbangan terdapat kemudahan akses untuk mendapatkan responden supir bis malam. Pengambilan data dilakukan pada bulan Mei 2007. Analisis kandungan energi dilakukan di Laboratorium Nutrisi, Fakultas Peternakan, IPB. Analisis kandungan kafein dilakukan di Balai Besar Industri Agro (BBIA) Bogor. Kedua analisis tersebut dilakukan pada bulan Juli 2007.

\section{Cara Pengambilan Contoh}

Contoh penelitian ini adalah supir bis malam dengan pertimbangan bahwa contoh tersebut merupakan konsumen tetap minuman berenergi yang mengonsumsi minuman berenergi secara rutin, memiliki pekerjaan yang berat serta mau diwawancarai. Teknik penarikan contoh dilakukan dengan cara convenience sampling. Contoh yang digunakan dalam penelitian ini sejumlah 36 orang.

Pemilihan sampel yang dianalisis kandungan energi dan kafein berdasarkan konsumsi merek minuman berenergi responden yang paling banyak, yaitu Extra Joss Serbuk, Hemaviton Jreng dan Kuku Bima Energy.

\section{Metode Analisis Kandungan Kafein}

Analisis yang dilakukan pada penelitian ini ada 2 jenis yaitu analisis kandungan energi dan analisis kandungan kafein. Metode yang digunakan untuk menganalisis kandungan energi yaitu menggunakan bomb calorimeter sedangkan analisis kandungan kafein menggunakan spektrofotometer.

\section{Łenis dan Cara Pengumpulan}

Data yang dikumpulkan berupa data primer yang meliputi karakteristik contoh, persepsi contoh (manfaat yang dirasakan serta efek dari konsumsi minuman berenergi), kebiasaan konsumsi minuman berenergi (frekuensi, jumlah, jenis, tempat pembelian, waktu konsumsi, alasan pembelian), serta preferensi contoh terhadap minuman berenergi. Data primer diperoleh dari wawancara dengan contoh dengan alat bantu kuesioner. Data primer lainnya adalah hasil analisis laboratorium tentang kandungan energi dan kandungan kafein pada minuman berenergi.

\section{Pengolahan dan Analisis Data}

Data diolah secara deskriptif dan inferensia dengan menggunakan perangkat lunak 
Microsoft Excel 2003 dan SPSS 11.5 for Windows.

Data primer meliputi karakteristik contoh, persepsi, kebiasaan konsumsi, dan preferensi ditabulasi dan diinterpretasikan secara deskriptif dengan tabel frekuensi dan tabulasi silang serta untuk mengetahui hubungan antar variabel dilakukan Uji Chi-Square. Data yang diolah secara deskriptif meliputi karakteristik contoh, konsumsi minuman berenergi, persepsi contoh dan preferensi contoh. Data primer lainnya adalah hasil analisis laboratorium yang diinterpretasikan secara deskriptif.

Pengkategorian frekuensi konsumsi dan jumlah konsumsi dibagi berdasarkan interval selang (Slamet, 1993). Data persepsi diolah secara deskriptif dan diberi skor. Selanjutnya dikategorikan menjadi persepsi baik jika jumlah skor persepsi lebih dari dua dan persepsi buruk jika jumlah skor persepsi kurang dari atau sama dengan dua dengan menggunakan perhitungan interval selang.

Data mengenai preferensi diukur dengan Skala Likert. Skala Likert tersebut meliputi Sangat Penting (skor 5), Penting (skor 4), Biasa (skor 3), Tidak Penting (skor 2) dan Sangat Tidak Penting (skor 1). Selanjutnya skor dari setiap atribut dijumlahkan kemudian dikategorikan berdasarkan perhitungan standar deviasi.

\section{HASIL DAN PEMBAHASAN}

\section{Karakteristik Contoh}

Hasil penelitian menunjukkan bahwa persentase terbesar umur contoh (33.3\%) berada pada kategori 31-37 tahun. Lebih dari separuh contoh (52.8\%) memiliki tingkat pendidikan SMP. Rata-rata pendapatan per bulan contoh adalah Rp 815 555.6 \$122 334.8 dengan persentase terbesar (44.4\%) berada pada tingkat pendapatan Rp 680001 - Rp 800000 per bulan. Rata-rata lama bekerja per hari contoh adalah $12.2 \pm 1.6$ jam/hari. Data tersebut secara lebih lengkap disajikan pada Tabel 1.

\section{Konsumsi Minuman Berenergi}

\section{Jenis dan Bentuk Minuman yang Dikonsumsi}

Kegiatan mengonsumsi pada penelitian ini merupakan perilaku atau tindakan meminum minuman berenergi. Minuman berenergi yang beredar di pasaran sangat beragam. Merek yang ditawarkan mulai dari Extra Joss, Hemaviton Jreng, Kuku Bima Energy, Kratingdaeng, M-150, Hemaviton Energy Drink, Fit Up Tablet, Fit Up Cair, Sakatonik Jreng, Extra Joss
Cair, Lipovitan dan lainnya. Tabel 2 menunjukkan merek minuman berenergi yang dikonsumsi contoh. Merek terbanyak yang dikonsumsi adalah Extra Joss sebesar 44.4\% (16 contoh), 19.4\% mengonsumsi merek Hemaviton Jreng dan 13.9\% mengonsumsi merek Kuku Bima Energy. Menurut Koentjaraningrat (1986) apabila perilaku konsumsi dilakukan berulangulang maka akan menjadi kebiasaan makan (Khumaidi, 1994).

Tabel 1. Sebaran Contoh berdasarkan Karakteristik contoh

\begin{tabular}{|c|c|c|}
\hline Karakteristik contoh & $\mathbf{n}$ & $\%$ \\
\hline \multicolumn{3}{|l|}{ Usia } \\
\hline 24-30 tahun & 9 & 25 \\
\hline 31-37 tahun & 12 & 33.3 \\
\hline 38-44 tahun & 10 & 27.8 \\
\hline 44-50 tahun & 5 & 13.9 \\
\hline Total & 36 & 100 \\
\hline Rata-rata \pm sd & \multicolumn{2}{|c|}{$36.5 \pm 6.5$} \\
\hline \multicolumn{3}{|l|}{ Pendidikan } \\
\hline Tidak sekolah & 1 & 2.8 \\
\hline SD/sederajat & 3 & 8.3 \\
\hline SMP/sederajat & 19 & 52.8 \\
\hline SMA/sederajat & 13 & 36.1 \\
\hline Perguruan tinggi/Akademi & 0 & 0 \\
\hline Total & 36 & 100 \\
\hline \multicolumn{3}{|l|}{ Pendapatan per bulan } \\
\hline$<680000$ & 4 & 11.1 \\
\hline $680001-800000$ & 16 & 44.4 \\
\hline $800001-920000$ & 11 & 30.6 \\
\hline > 920001 & 5 & 13.9 \\
\hline Total & 36 & 100 \\
\hline Rata-rata \pm sd & \multicolumn{2}{|c|}{$815555.6 \pm 122334.8$} \\
\hline \multicolumn{3}{|l|}{ J am kerja per hari } \\
\hline 10-13 jam & 31 & 86.1 \\
\hline >13 jam & 5 & 13.9 \\
\hline Total & 36 & 100 \\
\hline Rata-rata \pm sd & \multicolumn{2}{|c|}{$12.2 \pm 1.6$} \\
\hline
\end{tabular}

Tabel 2. Sebaran Contoh berdasarkan Merek yang Dikonsumsi

\begin{tabular}{lcc}
\hline Merek yang dikonsumsi & $\mathbf{n}$ & $\mathbf{\%}$ \\
\hline Extra Joss Serbuk & 16 & $\mathbf{4 4 . 4}$ \\
Hemaviton Jreng & 7 & 19.4 \\
Kuku Bima Energy & 5 & 13.9 \\
Kratingdaeng & 3 & 8.3 \\
M-150 & 2 & 5.6 \\
Hemaviton Energy Drink & 2 & 5.6 \\
Fit Up Tablet & 1 & 2.8 \\
Total & 36 & 100 \\
\hline
\end{tabular}


Kemasan merupakan salah satu alat penjualan paling vital dalam pemasaran karena produk akan mempunyai gambaran jelas dalam pikiran konsumen melalui kemasan. Sebesar $77.8 \%$ contoh mengonsumsi minuman berenergi dalam bentuk kemasan sachet, sebesar 19.4\% memilih kemasan botol dan hanya sedikit contoh $(2.8 \%)$ mengonsumsi minuman berenergi dalam bentuk tablet, yaitu Fit Up Tablet. Hal ini disebabkan karena kemasan sachet memiliki harga yang terjangkau, lebih mudah didapatkan di daerah tempat kerja serta praktis.

\section{Frekuensi Konsumsi Minuman Berenergi}

Rata-rata frekuensi konsumsi minuman berenergi contoh yaitu $8.7 \mathrm{kali} /$ minggu (Tabel 3). Lebih dari separuh contoh (55.6\%) termasuk dalam kategori sering (7-14 kali/minggu) mengonsumsi minuman berenergi, sementara itu terdapat $11.1 \%$ contoh yang termasuk dalam kategori sering. Menurut Sampoerno \& Fardiaz (2001), minuman berenergi yang termasuk ke dalam suplemen sebaiknya dikonsumsi secukupnya karena tujuannya hanya untuk melengkapi kebutuhan zat gizi yang belum mencukupi. Pada dasarnya fungsi suplemen adalah sebagai zat tambahan untuk memperbaiki dan meningkatkan daya tahan tubuh.

Tabel 3. Sebaran Contoh berdasarkan Frekuensi Konsumsi

\begin{tabular}{|c|c|c|}
\hline $\begin{array}{c}\text { Frekuensi Konsumsi } \\
\text { (kali/minggu) }\end{array}$ & $\mathbf{n}$ & $\%$ \\
\hline Jarang (< 7 kali/seminggu) & 12 & 33.3 \\
\hline Sering (7-14 kali/minggu) & 20 & 55.6 \\
\hline Selalu (>14 kali/minggu) & 4 & 11.1 \\
\hline Total & 36 & 100.0 \\
\hline Rata-rata \pm sd & $8.7 \pm 6.0$ & \\
\hline
\end{tabular}

\section{J umlah Konsumsi}

Jumlah konsumsi minuman berenergi contoh terbagi dalam kategori rendah, sedang dan tinggi dihitung berdasarkan banyaknya uks (ukuran kemasan saji) setiap kali mengonsumsi. Setiap satu ukuran kemasan saji memiliki berat sebesar 4 gram. Tabel 4 menunjukkan jumlah konsumsi contoh tiap kali minum (frekuensi minum). Hampir semua contoh (91.7\%) mengonsumsi satu buah (uks) dalam setiap kali minum sementara itu sedikit contoh (8.3\%) mengonsumsi langsung 2 buah (uks) minuman berenergi dengan alasan baru terasa khasiatnya jika langsung mengkonsumsi 2 uks minuman tersebut.
Tabel 4. Sebaran Contoh berdasarkan Banyaknya uks Setiap Kali Minum

\begin{tabular}{ccc}
\hline $\begin{array}{c}\text { Banyak uks setiap } \\
\text { minum }\end{array}$ & $\mathbf{n}$ & $\%$ \\
\hline 1 uks & 33 & $\mathbf{9 1 . 7}$ \\
2 uks & 3 & 8.3 \\
Total & 36 & 100.0 \\
\hline
\end{tabular}

Rata-rata jumlah konsumsi minuman berenergi per minggu yaitu 9.7 uks/minggu. Tabel 5 menunjukkan lebih dari separuh contoh $(66.7 \%)$ termasuk dalam kategori rendah sedangkan hanya sedikit contoh (2.8\%) termasuk dalam kategori tinggi dalam mengonsumsi minuman berenergi.

Tabel 5. Sebaran Contoh menurut Jumlah Konsumsi/Minggu

\begin{tabular}{lcc}
\hline J umlah konsumsi (uks/mgg) & $\mathbf{n}$ & $\%$ \\
\hline Rendah (<13 uks/mggu) & 24 & $\mathbf{6 6 . 7}$ \\
Sedang (13-27 uks/mggu) & 11 & 30.5 \\
Tinggi (> 27 uks/mggu) & 1 & 2.8 \\
\hline \multicolumn{1}{c}{ Total } & 36 & 100.0 \\
\hline \multicolumn{2}{c}{ Rata-rata \pm sd } & $9.72 \pm 8.266$ \\
\hline
\end{tabular}

\section{Alasan Konsumsi}

Tabel 6 menunjukkan bahwa sebagian besar contoh (75.0\%) mengonsumsi minuman berenergi dengan alasan sebagai penunjang aktivitas dan stamina, sementara itu hanya $5.6 \%$ yang beralasan karena rasanya yang enak dan segar. Menurut Sunarti et al. (1990), bekerja secara efektif dan produktif memerlukan ketahanan fisik yang baik artinya perlu daya yang cukup untuk melakukan berbagai pekerjaan. Daya (kekuatan) diperoleh dari makanan yang dikonsumsi. Merek minuman berenergi yang dipilih sebagai penunjang aktivitas dan stamina adalah Extra Joss.

Tabel 6. Sebaran Contoh berdasarkan Alasan Konsumsi Minuman Berenergi

\begin{tabular}{lcc}
\hline \multicolumn{1}{c}{ Alasan konsumsi } & $\mathbf{n}$ & $\%$ \\
\hline Rasanya segar dan enak & 2 & 5.6 \\
Penunjang aktivitas \& stamina & 27 & $\mathbf{7 5 . 0}$ \\
Minuman penyegar & 7 & 19.4 \\
Total & 36 & 100.0 \\
\hline
\end{tabular}

\section{Situasi Mengonsumsi}

Konsumen seringkali memilih suatu produk karena pertimbangan dari situasi saat mengonsumsi. Tabel 7 menunjukkan bahwa lebih dari separuh contoh (66.7\%) mengonsumsi saat bekerja karena contoh memerlukan tam- 
bahan energi. Makin berat pekerjaan yang dilakukan maka proses oksidasi dalam sel akan makin aktif dan mengakibatkan peningkatan energi yang dibutuhkan (Suhardjo \& Kusharto 1987).

Tabel 7. Sebaran Contoh berdasarkan Situasi Mengkonsumsi

\begin{tabular}{lcc}
\hline \multicolumn{1}{c}{ Situasi mengonsumsi } & $\mathbf{n}$ & $\%$ \\
\hline Akan bekerja & 1 & 2.8 \\
Sedang bekerja & 24 & $\mathbf{6 6 . 7}$ \\
Setelah bekerja & 7 & 19.4 \\
Saat akan bepergian jauh & 4 & 11.1 \\
Total & 36 & 100.0 \\
\hline
\end{tabular}

\section{Waktu Konsumsi}

Minuman berenergi biasanya dikonsumsi apabila contoh merasakan badan kurang bertenaga untuk melakukan aktivitas pekerjaan yaitu pada malam hari khususnya. Tabel 8 menunjukkan bahwa hampir separuh contoh (47.2\%) mengonsumsi minuman berenergi pada waktu malam hari. Sementara itu hanya $2.8 \%$ yang mengonsumsi pada pagi hari. Namun ada juga yang mengonsumsi pada waktu pagi, siang dan malam sebanyak $8.3 \%$.

Tabel 8. Sebaran Contoh berdasarkan Waktu Konsumsi

\begin{tabular}{lcc}
\hline \multicolumn{1}{c}{ Waktu Konsumsi } & $\mathbf{n}$ & $\%$ \\
\hline Pagi saja & 1 & 2.8 \\
Siang saja & 3 & 8.3 \\
Malam saja & 17 & $\mathbf{4 7 . 2}$ \\
Pagi dan siang & 6 & 16.8 \\
Pagi dan malam & 3 & 8.3 \\
Siang dan malam & 3 & 8.3 \\
Pagi, siang, malam & 3 & 8.3 \\
\hline
\end{tabular}

Sementara itu, dari segi waktu sebelum atau sesudah makan maka sebagian besar contoh $(97.2 \%)$ mengonsumsi minuman berenergi setelah makan (Tabel 9). Kandungan energi setelah mengonsumsi makanan akan mengakibatkan asupan bertambah. Apalagi ditambah dengan asupan minuman energi yang menyumbangkan energi juga walaupun dalam jumlah sedikit. Hal ini membuat contoh memiliki asupan energi yang lebih banyak sehingga diharapkan dapat bekerja lebih baik.

Tabel 9. Sebaran Contoh berdasarkan Waktu Konsumsi

\begin{tabular}{lcc}
\hline \multicolumn{1}{c}{ Waktu konsumsi } & $\mathbf{n}$ & \% \\
\hline Sebelum makan & 1 & 2.8 \\
Sesudah makan & 35 & $\mathbf{9 7 . 2}$ \\
Total & 36 & 100.0 \\
\hline
\end{tabular}

\section{Cara Penyajian}

Cara penyajian contoh berbeda-beda tergantung pilihan minuman berenergi. Tabel 10 menunjukkan bahwa sebesar $77.8 \%$ contoh hanya menambahkan air ketika mengonsumsi minuman berenergi. Biasanya minuman berenergi tersebut berbentuk serbuk sehingga diperlukan tambahan air. Bila minuman berenergi sudah dalam bentuk siap saji biasanya dalam kemasan botol maka contoh bisa langsung mengonsumsinya. Berdasarkan pengamatan, lebih dari separuh contoh menyajikan dengan ditambah air karena minuman berenergi yang dipilih berbentuk sachet (serbuk dalam kemasan) dan sudah menjadi satu paket dengan air mineral gelas. Harganya pun relatif lebih murah jika dibandingkan dengan minuman berenergi yang langsung minum (kemasan botol).

Tabel 10. Sebaran Contoh berdasarkan Cara Penyajian

\begin{tabular}{lcc}
\hline \multicolumn{1}{c}{ Cara penyajian } & $\mathbf{n}$ & \% \\
\hline Langsung diminum & 8 & 22.2 \\
Ditambah air saja & 28 & $\mathbf{7 7 . 8}$ \\
Total & 36 & 100.0 \\
\hline
\end{tabular}

\section{Kandungan Energi dan Kafein}

Minuman berenergi yang terpilih untuk dianalisis kandungan energi dan kafein adalah 3 merek minuman berenergi terbanyak pilihan contoh yaitu Ekstra Joss Serbuk (44.4\% contoh), Hemaviton Jreng $(19.4 \%$ contoh) dan Kuku Bima Energy (13.9\% contoh). Berdasarkan hasil analisis kandungan energi dengan menggunakan bomb kalorimeter didapatkan hasil sebagai berikut (Tabel 11).

Tabel 11. Sebaran Merek Minuman Berenergi berdasarkan Kandungan Energi

\begin{tabular}{lcc}
\hline Minuman Berenergi & $\begin{array}{c}\text { Kandungan } \\
\text { Energi } \\
\text { (Kal/g) }\end{array}$ & $\begin{array}{c}\text { Kandungan } \\
\text { Energi } \\
\text { (Kal/uks) }\end{array}$ \\
\hline Extra Joss Serbuk & 4.278 & 17.112 \\
Hemaviton Jreng & 2.599 & 10.396 \\
Kuku Bima Energy & 2.720 & 10.880 \\
\hline
\end{tabular}

Kandungan energi dari ketiga minuman berenergi tersebut memiliki perbedaan. Merek Ekstra Joss Serbuk memiliki kandungan energi terbesar di antara kedua merek lainnya yaitu sebesar $4.278 \mathrm{Kal} /$ gram. Kedua merek lainnya memiliki kandungan energi sekitar setengah dari merek Extra Joss. Hal ini diduga karena adanya perbedaan komposisi pada minuman tersebut baik dalam hal jumlah maupun bahan penyusunnya. Kandungan energi pada ketiga 
sampel sangat kecil. Ketiga jenis minuman berenergi itu dalam bentuk serbuk. Pada minuman berenergi bentuk cair (kemasan botol) biasanya mengandung $100 \mathrm{Kal}$ per $150 \mathrm{ml}$.

Sumber energi pada minuman berenergi ini bersumber dari kandungan gula yang terdapat pada minuman berenergi. Namun gula yang digunakan pada minuman berenergi selain gula pasir juga digunakan pemanis buatan yaitu aspartam. Aspartam termasuk ke dalam kelompok pemanis rendah kalori dan memiliki tingkat kemanisan 160 hingga 220 kali dari gula (Syah \& Utama, 2005).

Untuk analisis kandungan kafein digunakan spektrofotometer. Tabel 12 menunjukkan bahwa ketiga merek yang dianalisis memiliki kandungan kafein yang tidak jauh berbeda yaitu berkisar antara $7688 \mathrm{mg} / \mathrm{kg}$ hingga 9252 $\mathrm{mg} / \mathrm{kg}$ atau sekitar $30.752 \mathrm{mg} / \mathrm{uks}$ hingga $37.008 \mathrm{mg} / \mathrm{uks}$. Hal ini disebabkan oleh jumlah yang berbeda dari penambahan kafein pada masing-masing merek. Kandungan kafein pada minuman berenergi yang dianalisis termasuk kategori aman jika dibandingkan dengan batas penggunaannya.

Tabel 12. Sebaran Merek Minuman Berenergi berdasarkan Kandungan Kafein

\begin{tabular}{lcc}
\hline Minuman Berenergi & $\begin{array}{c}\text { Kandungan } \\
\text { Kafein } \\
\text { (mg/ kg) }\end{array}$ & $\begin{array}{c}\text { Kandungan } \\
\text { Kafein } \\
\text { (mg/ uks) }\end{array}$ \\
\hline Ekstra Joss Serbuk & 8778 & 35.112 \\
Hemaviton Jreng & 7688 & 30.752 \\
Kuku Bima Energy & 9252 & 37.008 \\
\hline
\end{tabular}

Kafein merupakan senyawa alkaloid pahit yang ditemukan pada kopi dan teh, termasuk ke dalam golongan methylxantine (Groff \& Groper, 2005). Kafein dapat merangsang metabolisme tubuh. Mekanisme ini akan meningkatkan tekanan darah, pengeluaran urine, dan aktivitas sistem saraf pusat. Ciri-cirinya, napas menjadi cepat, otot menjadi kaku, dan aliran darah dalam otak meningkat. Kafein dengan mudah diserap usus dan menyebar dalam beberapa menit melalui darah ke semua organ dan jaringan tubuh. Kafein dapat menolong, mencegah, atau menghilangkan kelelahan dan meningkatkan kewaspadaan.

Sumber kafein utama adalah kopi. Kandungan kafein pada kopi berbeda-beda yaitu kopi instan (40 hingga $108 \mathrm{mg} /$ penyajian) dan kopi saring (64 hingga 128 mg/penyajian). Kandungan kafein bervariasi pada kopi, dipengaruhi oleh spesies tanaman kopinya, tipe pengolahan (contohnnya kopi giling atau instan), metode pemasakan (yaitu saring atau tetes), jumlah kopi yang digunakan, dan lamanya waktu pemasakan (Graham dalam Kanarek \& Kaufman, 1991).

Batas aman penggunaan kafein adalah $150 \mathrm{mg} /$ orang/hari. Menurut BPOM, minuman berenergi yang ada di Indonesia mengandung kafein sejumlah $50 \mathrm{mg} /$ botol dan hanya dibolehkan mengonsumsi sebanyak tiga botol/hari. Kemudian label dalam botol harus mencantumkan peringatan keras bagi penderita penyakit gula, darah tinggi, dan jantung. Selain itu, bagi penderita yang mempunyai tingkat sensitivitas tinggi, seperti sensitif terhadap kafein, harus berhati-hati mengonsumsi produk ini. Jumlah kafein yang berlebihan dapat memperburuk ketidakstabilan emosi dan gangguan mental.

\section{Karakteristik Produk}

\section{Tempat Membeli}

Produk pangan seperti minuman berenergi bisa didapatkan di berbagai tempat mulai dari pasar, toko, supermarket bahkan dari pedagang asongan baik secara eceran maupun tidak. Lebih dari sepertiga contoh (77.2\%) membeli produk minuman berenergi di warung atau toko (Tabel 13) yang berada dekat dengan tempat kerjanya misalnya di terminal atau tempat pemberhentian sementara bis.

Tabel 13. Sebaran Contoh berdasarkan Tempat Membeli Minuman Berenergi

\begin{tabular}{lcc}
\hline \multicolumn{1}{c}{ Tempat pembelian } & $\mathbf{n}$ & \% \\
\hline Warung/toko & 26 & $\mathbf{7 2 . 2}$ \\
Pedagang asongan & 10 & 27.8 \\
\hline
\end{tabular}

\section{Harga}

Harga adalah sejumlah nilai yang harus dikeluarkan konsumen untuk mendapatkan barang atau jasa. Harga pada minuman berenergi beragam mulai dari Rp 1000 sampai Rp 3500 per kemasan. Rata-rata harga minuman berenergi dengan kemasan sachet adalah Rp 1000 dan Rp 3500 untuk kemasan botol. Mayoritas contoh (83.3\%) menyatakan harga minuman berenergi yang biasa dibeli termasuk kategori sedang. Sementara itu, sejumlah $16.7 \%$ contoh menyatakan pada kategori murah terhadap minuman berenergi yang dikonsumsinya. Harga pada penelitian ini bukan berdasarkan merek yang dikonsumsi namun berdasarkan sejumlah uang yang contoh keluarkan untuk membeli minuman berenergi. 


\section{Klaim dan Registrasi Minuman Berenergi}

Kelengkapan label pangan pada minuman berenergi berbeda. Menurut Nielsen (1998), standar informasi gizi pada label pangan terdiri atas: (1) ukuran persajian, (2) petunjuk pemakaian, (3) jumlah zat gizi serta Angka Kecukupan Gizi masing-masing, dan (4) memiliki acuan berdasarkan \%AKG pada 2000 Kalori atau 2500 Kalori. Selain itu, kelengkapan pada label pangan juga meliputi nama merek, nomor registrasi, klaim, halal, nama dan alamat produsen, komponen yang digunakan, cara penggunaan dan penyimpanan, berat bersih, kode produksi, informasi komponen nilai gizi, serta tanggal dan bulan kadaluarsa.

Klaim adalah pernyataan mengenai kelebihan relatif suatu produk dibandingkan pesaingnya. Menurut Peraturan Pemerintah RI Nomor 69 Tahun 1999 tentang Label dan Iklan Pangan pernyataan (klaim) tentang manfaat kesehatan adalah pernyataan bahwa produk pangan tertentu mengandung gizi dan atau zat non gizi tertentu yang bermanfaat jika dikonsumsi atau tidak boleh dikonsumsi bagi kelompok tertentu (Peraturan Pemerintah Republik Indonesia Nomor 69 Tahun 1999).

Klaim pada penelitian ini diamati langsung pada produk minuman berenergi (pada kemasan). Berdasarkan hal tersebut maka dapat diketahui bahwa klaim-klaim yang diungkapkan pada produk minuman berenergi pada kemasan termasuk ke dalam klaim subyektif yaitu produsen lebih menonjolkan manfaat psikososial yang sulit dilakukan pembuktiannya secara ilmiah. Contohnya, pada klaim minuman berenergi Kuku Bima Energy disebutkan "Minuman Para Juara". Selain itu ada pula klaim yang membingungkan konsumen seperti pada merek $M-150$ yang menyatakan bahwa "M-150 bisa!". Klaim tersebut tidak menjelaskan apa maksud serta kaitannya dengan produk minuman berenergi tersebut.

Selain itu terdapat juga klaim yang menonjolkan kandungan gizi terkait dengan minuman berenergi. Klaim ini dapat dijumpai pada merek Extra Joss Active dan Hemaviton Jreng. Klaim "Energi 7 Vitamin B" pada Extra Joss Active menunjukkan bahwa produk tersebut mengandung energi dan berbagai macam vitamin $B$ seperti vitamin B1, vitamin B2, vitamin B3 dan sebagainya. Begitu pula dengan klaim pada Hemaviton Jreng yang menyatakan "Energi Vitamin T8".

Beberapa minuman berenergi ada yang tidak mencantumkan klaim pada kemasan seperti Hemaviton Energy Drink dan Fit Up Tab- let dan beberapa lainnya mencantumkan klaimnya. Perbedaan pencantuman klaim terse but memiliki tujuan atau sasaran yang berbeda. Hal ini didukung oleh fungsi iklan yang bertujuan untuk menarik perhatian konsumen agar membeli atau menggunakan produk minuman berenergi tersebut.

Komponen utama pada minuman berenergi adalah kafein, vitamin B dan taurin. Kafein berfungsi sebagai stimulan atau perangsang susunan saraf pusat. Vitamin B dan taurin berfungsi sebagai koenzim yang membantu metabolisme energi di dalam tubuh. Kombinasi antara kafein dan taurin dalam minuman berenergi akan merangsang sistem saraf pusat untuk memicu reaksi katabolisme (reaksi untuk menghasilkan energi) di otot. Mekanismenya melalui pengaktifan kerja saraf yang menghasilkan percepatan denyut jantung untuk memompa darah dan oksigen, serta menstimulasi peningkatan kadar gula darah. Reaksi katabolisme akan lebih teraktifkan dengan penambahan vitamin-vitamin terutama vitamin B.

Almatsier (2003) menyatakan bahwa tiap vitamin B dalam bentuk koenzim terlibat secara langsung maupun tidak langsung dalam metabolisme energi. Beberapa koenzim merupakan fasilitator dalam reaksi-reaksi pelepasan energi. Dengan demikian, terlihat bahwa setiap vitamin B saling berkaitan dalam fungsinya sebagai koenzim dalam metabolisme energi.

Komponen lainnya seperti royal jelly, madu, asam sitrat dan sebagainya hanya sebagai tambahan saja agar memiliki rasa yang dapat disukai oleh konsumen. Komponen tersebut berbeda pada setiap merek minuman berenergi. Selain itu istilah yang digunakannya pun berbeda, hal ini dapat dilihat dengan adanya beberapa merek yang menggunakan bahasa ilmiah dan terkadang menggunakan istilah yang berbeda seperti komposisi kafein yang dicantumkan dengan nama yang berbeda. Pada merek Extra Joss, kafein dituliskan dengan nama "caffein" sedangkan pada Hemaviton Jreng menggunakan istilah " $1,3,7$ trimethylxantine". Begitu juga dengan nama istilah vitamin B kompleks yang berbeda setiap mereknya.

Pemanis buatan yang digunakan pada minuman berenergi adalah aspartam. Menurut Ramsey (2001) aspartam merupakan pemanis buatan dengan kalori rendah. Aspartam ini memiliki tingkat kemanisan 160 hingga 220 kali dari gula. 


\section{Persepsi Contoh}

Persepsi adalah penafsiran yang unik terhadap suatu situasi, bukan merupakan suatu pencarian yang sebenarnya dari situasi tersebut. Persepsi berhubungan dengan pendapat atau penilaian terhadap suatu stimulus (Langevelt dalam Hariyanto, 2001). Persepsi juga tidak hanya bergantung pada rangsangan fisik saja tetapi juga pada rangsangan sekitar (lingkungan) ataupun keadaan individu sendiri.

\section{Persepsi terhadap Manfaat}

Persepsi contoh terhadap minuman berenergi berkaitan dengan manfaat yang dirasakan secara langsung. Hal ini menunjukkan manfaat secara fungsional yaitu manfaat yang dirasakan konsumen secara fisiologis (Sumarwan, 2003). Tabel 14 menunjukkan bahwa mayoritas contoh (88.9\%) merasakan secara langsung badannya terasa segar. Hal ini contoh rasakan dengan ciri yaitu setelah mengonsumsi minuman berenergi badan yang tadinya terasa loyo menjadi segar dan bersemangat. Sementara itu, manfaat badan terasa berenergi dirasakan juga oleh hampir seluruh contoh (91.7\%) yang ditandai dengan semakin kuat dan penuh konsentrasi untuk menjalankan pekerjaannya. Tidak hanya itu, manfaat lainnya yaitu tidak cepat lelah juga dirasakan oleh lebih dari separuh contoh (58.3\%) karena contoh menganggap telah memiliki tenaga lebih untuk melakukan pekerjaannya akibat konsumsi minuman berenergi tersebut. Manfaat lain yang dirasakan adalah tidak cepat mengantuk menurut $55.6 \%$ contoh. Hal ini diduga disebabkan oleh adanya kandungan kafein pada minuman berenergi yang memberikan efek terjaga bagi yang mengonsumsinya (Khomsan, 2004).

Tabel 14. Sebaran Contoh berdasarkan Persepsi terhadap Manfaat yang Dirasakan

\begin{tabular}{|c|c|c|c|c|c|c|c|c|}
\hline \multirow{2}{*}{$\begin{array}{c}\text { Keadaan } \\
\text { contoh }\end{array}$} & \multicolumn{2}{|c|}{ Ya } & \multicolumn{2}{|c|}{ Tidak } & \multicolumn{2}{|c|}{ Biasa } & \multicolumn{2}{|c|}{ Total } \\
\hline & $n$ & $\%$ & $n$ & $\%$ & $n$ & $\%$ & $n$ & $\%$ \\
\hline $\begin{array}{l}\text { Badan terasa } \\
\text { segar }\end{array}$ & 32 & 88.9 & 0 & 0 & 4 & 11.1 & 36 & 100 \\
\hline $\begin{array}{l}\text { Badan terasa } \\
\text { berenergi }\end{array}$ & 33 & 91.7 & 0 & 0 & 3 & 8.3 & 36 & 100 \\
\hline $\begin{array}{l}\text { Tidak cepat } \\
\text { lelah }\end{array}$ & 21 & 58.3 & 1 & 2.8 & 14 & 38.9 & 36 & 100 \\
\hline $\begin{array}{l}\text { Tidak } \\
\text { mengantuk }\end{array}$ & 20 & 55.6 & 3 & 8.3 & 13 & 36.1 & 36 & 100 \\
\hline $\begin{array}{l}\text { Jantung } \\
\text { terasa } \\
\text { berdetak }\end{array}$ & 1 & 2.8 & 23 & 63.9 & 12 & 33.3 & 36 & 100 \\
\hline
\end{tabular}

Selanjutnya, persepsi yang dirasakan oleh contoh diberi skor berdasarkan manfaatnya dan didapatkan bahwa sebagian besar con- toh (72.2\%) memiliki persepsi yang baik terhadap manfaat mengonsumsi minuman berenergi (Tabel 15). Persepsi yang baik ini didukung oleh persepsi contoh yang menganggap bahwa setelah mengonsumsi minuman berenergi, maka akan memperoleh manfaat yang dapat mendukung aktivitasnya sebagai supir bis malam yang membutuhkan tenaga serta konsentrasi tinggi. Persepsi buruk contoh menandakan bahwa contoh hanya mendapat sedikit manfaat dari mengonsumsi minuman berenergi.

Tabel 15. Sebaran Contoh berdasarkan Kategori Persepsi

\begin{tabular}{lcc}
\hline \multicolumn{1}{c}{ Persepsi } & n & \% \\
\hline Persepsi buruk $(\leq 2)$ & 10 & 27.8 \\
Persepsi baik $(>2)$ & 26 & $\mathbf{7 2 . 2}$ \\
Total & 36 & 100.0 \\
\hline
\end{tabular}

\section{Persepsi Klaim terhadap Manfaat}

Tabel 16 menunjukkan bahwa sebagian besar contoh (55.6\%) percaya terhadap manfaat sesuai dengan iklan atau klaim pada setiap minuman berenergi secara keseluruhan. $\mathrm{Hal}$ ini disebabkan contoh merasakan sendiri manfaatnya berdasarkan pengalaman mengonsumsi minuman berenergi. Jenis-jenis klaim dijelaskan pada bagian karakteristik produk. Kepercayaan yang baik terhadap klaim gizi merek yang biasa digunakan merupakan bentuk kepercayaan deskriptif. Menurut Sumarwan (2003), kepercayaan atau pengetahuan konsumen menyangkut kepercayaan bahwa suatu produk memiliki berbagai atribut dan manfaat dari berbagai atribut tersebut. Kepercayaan konsumen terhadap suatu produk, atribut, dan manfaat produk menggambarkan persepsi konsumen. Oleh karena itu, kepercayaan akan berbeda di antara konsumen. Konsumen akan memberikan kepercayaan yang tinggi karena pengalamannya menggunakan secara langsung suatu produk (Kardes, 2002).

\section{Persepsi Lainnya}

Contoh juga memiliki persepsi terhadap waktu reaksi dan lama efek yang dirasakan setelah mengonsumsi minuman berenergi. Masing-masing contoh memiliki pandangan berbeda-beda mengenai hal tersebut. Tabel 15 menunjukkan bahwa sebagian besar contoh (55.6\%) menyatakan bahwa reaksi dari awal mengonsumsi hingga manfaat yang dirasakan termasuk dalam kategori biasa. Sementara itu sebesar $11.1 \%$ menyatakan bahwa reaksi minuman berenergi sangat cepat hingga dapat dirasakan manfaatnya secara langsung. Hal ini 
tentunya dipengaruhi oleh faktor individu sendiri dan metabolisme individu tersebut. Minuman berenergi yang dianggap kategori sangat cepat reaksinya adalah Kratingdaeng, sedangkan kategori cepat reaksinya adalah Extra Joss Serbuk.

Tabel 16. Sebaran Contoh berdasarkan Kepercayaan terhadap Manfaat dan Kecepatan Reaksi

\begin{tabular}{lcc}
\hline Kepercayaan terhadap manfaat & $\mathbf{n}$ & $\%$ \\
\hline Percaya & 20 & $\mathbf{5 5 . 6}$ \\
Biasa & 16 & 44.4 \\
Total & 36 & 100.0 \\
\hline Persepsi terhadap reaksi & & \\
\hline Sangat cepat $(<15$ menit) & 4 & 11.1 \\
Cepat (15-60 menit) & 12 & 33.3 \\
Biasa (>60 menit) & 20 & $\mathbf{5 5 . 6}$ \\
Total & 36 & 100.0 \\
\hline
\end{tabular}

Tabel 17 menunjukkan bahwa lebih dari separuh contoh (63.9\%) merasakan efek manfaat dari minuman berenergi hanya satu hingga dua jam saja. Sebanyak $27.8 \%$ contoh menyatakan efeknya tiga hingga empat jam dan sebanyak $8.3 \%$ menyatakan efeknya lima hingga enam jam. Menurut Siregar (2005), kafein diabsorbsi secara sempurna dalam system pencernaan selama 30-60 menit. Maksimum efek yang terjadi di otak akan muncul dalam waktu 2 jam sehingga kafein tidak berefek dengan langsung. Minuman berenergi yang memiliki efek lama pada penelitian ini yaitu merek Kratingdaeng dan $\mathrm{M}-150$.

Tabel 17. Sebaran Contoh berdasarkan Persepsi terhadap Lamanya Efek Minuman Berenergi

\begin{tabular}{ccc}
\hline $\begin{array}{c}\text { Persepsi terhadap } \\
\text { lamanya efek }\end{array}$ & $\mathbf{n}$ & $\%$ \\
\hline 1-2 jam & 23 & 63.9 \\
$3-4$ jam & 10 & 27.8 \\
$5-6$ jam & 3 & 8.3 \\
Total & 36 & 100.0 \\
\hline
\end{tabular}

Seluruh contoh (100\%) mengungkapkan tidak mengalami keluhan ketika mengonsumsi minuman berenergi (Tabel 18). Hal ini dipertegas contoh bahwa yang dirasakan hanyalah manfaatnya tanpa ada efek sampingnya. Keluhan pada penelitian ini merupakan segala penyakit atau gangguan yang terjadi pada tubuh contoh saat mengonsumsi minuman berenergi misalnya perut terasa sakit atau kepala pusing. Walaupun demikian sebagian contoh (58.3\%) mengalami ketergantungan atau ketagihan apabila tidak mengonumsi minuman ber- energi sehingga contoh merasa bahwa tidak bertenaga saat melakukan aktivitas (Tabel 18). Jadi contoh akan terus mengonsumsi minuman berenergi.

Tabel 18. Sebaran Contoh berdasarkan Keluhan dan Efek Bila Tidak Mengonsumsi Minuman Berenergi

\begin{tabular}{lcc}
\hline \multicolumn{1}{c}{ Keluhan } & $\mathbf{n}$ & $\%$ \\
\hline Ya & 0 & 0 \\
Tidak & 36 & $\mathbf{1 0 0 . 0}$ \\
\hline Efek bila tidak mengonsumsi & & \\
\hline Biasa saja & 15 & 41.7 \\
Tidak bertenaga & 21 & $\mathbf{5 8 . 3}$ \\
\hline
\end{tabular}

\section{Preferensi Contoh}

Preferensi adalah derajat kesukaan, pilihan atau sesuatu hal yang lebih disukai oleh konsumen (Assael, 1992). Preferensi konsumen juga merupakan gambaran mengenai kombinasi barang dan jasa yang lebih disukai konsumen apabila ia memiliki kesempatan untuk memperolehnya. Preferensi setiap orang berbedabeda berdasarkan atribut yang diutamakannya.

Pada penelitian ini preferensi diukur dengan melihat kepentingan dari berbagai atribut pada produk minuman berenergi seperti rasa, kandungan gizi, keamanan efek samping, manfaat penambah energi, manfaat penunjang aktivitas, kepraktisan konsumsi, harga, serta kecepatan reaksi. Tabel 19 menunjukkan separuh contoh (50\%) memilih atribut rasa dalam kategori biasa sedangkan sebanyak $22.2 \%$ contoh merasa sangat penting dalam pemilihan atribut rasa. Rasa merupakan salah satu indikator seseorang untuk mengonsumsi pangan seperti dalam pemilihan minuman berenergi, yang memiliki rasa asam, manis, bahkan pahit yang disebabkan zat-zat yang terkandung di dalamnya. Contoh menyukai rasa asam yang terdapat pada minuman berenergi.

Pada atribut kandungan gizi, sebanyak 41.7\% contoh termasuk kategori biasa namun terdapat 36.1 persen contoh yang menyatakan sangat penting untuk melihat kandungan gizi minuman berenergi. Hal ini diasumsikan karena pendidikan contoh yang rata-rata pada tingkat SMP sehingga memiliki pengetahuan yang terbatas mengenai kandungan gizi yang ada pada minuman berenergi. Pada saat wawancara pun kebanyakan contoh tidak mengerti akan istilah-istilah yang terdapat pada kemasan minuman berenergi.

Pada atribut keamanan efek samping, $25 \%$ contoh menyatakan sangat penting, $38.9 \%$ 
contoh menyatakan penting, $30.6 \%$ contoh menyatakan biasa saja dan tidak ada contoh yang menyatakan tidak penting serta sangat tidak penting. Berdasarkan hal itu, contoh tampaknya sangat memperhatikan terhadap efek samping terhadap kesehatannya. Sementara itu, pada atribut manfaat penambah energi dan manfaat penunjang aktivitas paling banyak contoh me milih kategori penting. Hal ini disebabkan tujuan contoh yang menginginkan adanya asupan energi yang lebih sehingga dapat menunjang aktivitas kerja terutama pada saat mengendarai bis.

Kepraktisan pada saat konsumsi tidak menjadi pilihan yang penting bagi contoh. Tabel 19 menunjukkan separuh contoh (52.7\%) memilih kategori biasa dalam kepraktisan konsumsi. Hal ini diasumsikan bahwa contoh tidak terlalu memperdulikan atribut lainnya saat mengonsumsi minuman berenergi tetapi hanya ingin mendapatkan manfaatnya saja. Bahkan terdapat contoh $(11.1 \%)$ yang menganggap tidak penting terhadap atribut kepraktisan mengonsumsi.

Pada atribut harga, lebih dari separuh contoh $(66.7 \%)$ memilih kategori biasa karena menurut contoh akan tetap membeli minuman berenergi berapa pun harganya. Sementara itu, hanya terdapat empat orang yang memilih harga sebagai atribut yang sangat penting. Engel et al. (1994) menyatakan konsumen kerap mengungkapkan sedikit pertimbangan mengenai harga. Faktor lainnya seperti manfaat kesehatan dan rasa mungkin dianggap lebih penting.

Atribut terakhir yaitu kecepatan reaksi yang dipilih sebagian contoh (58.3\%) dalam kategori biasa. Hal ini sejalan dengan alasan pada saat memilih atribut lainnya dimana tujuan mengonsumsi minuman berenergi untuk mendapatkan manfaatnya.
Selanjutnya, preferensi dilakukan skoring dan dibagi menjadi tiga kategori yaitu kategori preferensi rendah, preferensi sedang dan preferensi tinggi. Tabel 20 menunjukkan bahwa sebanyak $72.2 \%$ contoh termasuk dalam kategori preferensi sedang. Preferensi kategori tinggi contoh ditunjukkan dengan banyaknya pilihan contoh terhadap atribut dari minuman berenergi yang termasuk sangat penting atau pun penting, sedangkan kategori rendah contoh ditunjukkan sebaliknya. Hal ini menunjukkan seberapa penting setiap atribut pada minuman berenergi.

Tabel 20. Sebaran Contoh berdasarkan Kategori Preferensi

\begin{tabular}{lcc}
\hline \multicolumn{1}{c}{ Kategori preferensi } & $\mathbf{n}$ & $\%$ \\
\hline Rendah $(<26)$ & 5 & 13.9 \\
Sedang $(26-33)$ & 26 & $\mathbf{7 2 . 2}$ \\
Tinggi $(>33)$ & 5 & 13.9 \\
Total & 36 & 100.0 \\
\hline
\end{tabular}

\section{Pemilihan Merek dan Alasannya}

Merek adalah nama penting bagi sebuah produk atau jasa serta merupakan simbol dan indikator kualitas sebuah produk (Sumarwan, 2003). Merek-merek produk yang sudah lama dikenal konsumen telah menjadi citra bahkan simbol status bagi produk tersebut. Tabel 6 menunjukkan contoh yang memilih merek Extra Joss Serbuk (44.4\%), Hemaviton Jreng (19.4\%), Kuku Bima Energy (13.9\%), Kratingdaeng (8.3\%), $M-150$ (5.6\%), Hemaviton Energy Drink (5.6\%), dan Fit Up Tablet (2.8\%). Alasan contoh memilih masing-masing minuman berenergi tersebut karena lebih terasa bermanfaat $(58.3 \%)$, rasanya yang enak $(16.7 \%)$ sementara sebesar $5.6 \%$ contoh beralasan karena tidak ada efek sampingnya (Tabel 21).

Tabel 19. Sebaran Contoh berdasarkan Preferensi Minuman Berenergi

\begin{tabular}{|c|c|c|c|c|c|c|c|}
\hline No & Atribut & $\begin{array}{l}\text { SP } \\
\%\end{array}$ & $\begin{array}{l}\mathbf{P} \\
\%\end{array}$ & $\begin{array}{c}\text { BS } \\
\%\end{array}$ & $\begin{array}{c}\text { TP } \\
\%\end{array}$ & $\begin{array}{c}\text { STP } \\
\%\end{array}$ & $\begin{array}{c}\text { Total } \\
\%\end{array}$ \\
\hline 1 & Rasa & 22.2 & 27.8 & 50 & 0 & 0 & 100.0 \\
\hline 2 & Kandungan gizi & 36.1 & 22.2 & 41.7 & 0 & 0 & 100.0 \\
\hline 3 & Keamanan efek samping & 25 & 38.9 & 30.6 & 5.5 & 0 & 100.0 \\
\hline 4 & Manfaat penambah energi & 30.6 & 61.1 & 8.3 & 0 & 0 & 100.0 \\
\hline 5 & Manfaat penunjang aktivitas & 36.1 & 44.4 & 19.5 & 0 & 0 & 100.0 \\
\hline 6 & Kepraktisan konsumsi & 5.6 & 30.6 & 52.7 & 11.1 & 0 & 100.0 \\
\hline 7 & Harga & 11.1 & 22.2 & 66.7 & 0 & 0 & 100.0 \\
\hline 8 & Kecepatan reaksi & 8.3 & 30.6 & 58.3 & 2.8 & 0 & 100.0 \\
\hline
\end{tabular}

Keterangan: $\mathrm{SP}=$ Sangat Penting; $\mathrm{P}=$ Penting; $\mathrm{BS}=$ Biasa;

TP = Tidak Penting; STP = Sangat Tidak Penting 
Tabel 21. Sebaran Contoh berdasarkan Alasan Pemilihan Merek

\begin{tabular}{lcc}
\hline \multicolumn{1}{c}{ Alasan } & $\mathbf{n}$ & $\%$ \\
\hline Harga murah & 4 & 11.1 \\
Rasanya enak & 6 & 16.7 \\
Lebih terasa bermanfaat & 21 & $\mathbf{5 8 . 3}$ \\
Tidak ada efek samping & 2 & 5.6 \\
Praktis dlm penyajian & 3 & 8.3 \\
Total & 36 & 100.0 \\
\hline
\end{tabular}

\section{Loyalitas Merek}

Menurut Sumarwan (2003), loyalitas merek adalah sikap positif seorang konsumen terhadap suatu merek, konsumen memiliki keinginan kuat untuk membeli ulang produk yang sama pada saat sekarang maupun masa datang. Mowen dan Minor (1998) diacu dalam Sumarwan (2003) mengemukakan ada dua pendekatan untuk memahami loyalitas merek yaitu dengan pendekatan perilaku dan pendekatan sikap.

Tabel 22 menunjukkan bahwa masingmasing sebanyak $36.1 \%$ contoh menyatakan akan membeli di tempat lain dan membeli merek lain apabila tidak mendapatkan minuman berenergi yang diinginkan. Sejumlah $27.8 \%$ contoh menyatakan akan menunda pembelian. Loyalitas ditunjukkan dengan pembelian kembali secara konsisten terhadap suatu produk. Pada jawaban contoh yang menunjukkan loyalitas merek yaitu menunda pembelian serta membeli merek yang dikonsumsi di tempat lainnya. Dengan demikian, terdapat $63.9 \%$ contoh yang loyal terhadap merek minuman berenergi tertentu.

Selain itu, loyalitas terhadap minuman berenergi dapat disebabkan karena dapat membantu metabolisme energi walaupun kandungan energinya kecil dan juga kandungan kafein yang kecil.

Tabel 22. Sebaran Contoh berdasarkan Loyalitas Merek

\begin{tabular}{llc}
\hline \multicolumn{1}{c}{ Loyalitas merek } & $\mathbf{n}$ & $\%$ \\
\hline Membeli merek lain & 13 & 36.1 \\
Menunda pembelian & 10 & 27.8 \\
Membeli di tempat lain & 13 & 36.1 \\
\hline
\end{tabular}

\section{Lama Penggunaan Merek Minuman Berenergi}

Lama penggunaan merek minuman berenergi contoh tergantung pada loyalitasnya. Bila seseorang merasakan banyak manfaat serta cocok maka biasanya akan terus mengonsumsi merek tersebut. Tabel 23 menunjukkan lebih dari sepertiga contoh (38.8\%) menggunakan merek selama duabelas hingga dua puluh empat bulan.
Tabel 23. Sebaran Contoh berdasarkan Lama Penggunaan

\begin{tabular}{lcc}
\hline \multicolumn{1}{c}{ Lama penggunaan } & $\mathbf{n}$ & $\%$ \\
\hline$>24$ bulan & 11 & 30.6 \\
$12-24$ bulan & 14 & $\mathbf{3 8 . 8}$ \\
$<12$ bulan & 11 & 30.6 \\
Total & 36 & 100.0 \\
\hline
\end{tabular}

\section{Hubungan antara Karakteristik Contoh dengan Persepsi}

Umur antara 31 hingga 37 tahun memiliki persepsi baik, sedangkan persepsi buruk terdapat pada golongan umur lebih dari 44 tahun. Hasil uji Chi-Square menunjukkan bahwa umur contoh dan persepsi tidak berhubungan ( $p>0.05)$. Hal ini menunjukkan bahwa persepsi mengenai minuman berenergi tidak tergantung pada umur seseorang.

Hasil uji Chi-Square menunjukkan bahwa tingkat pendidikan dan persepsi tidak berhubungan $(p>0.05)$. Hal ini diduga karena persepsi yang dimaksud dalam penelitian ini adalah persepsi akan manfaat yang dirasakan secara langsung, sehingga pendidikan contoh tidak berpengaruh pada persepsi terhadap minuman berenergi.

Responden dengan pendapatan per bulan Rp 680001 hingga Rp 800000 (81.8\%) memiliki persepsi yang baik. Hasil uji Chi-Square menunjukkan bahwa pendapatan dengan persepsi tidak berhubungan nyata, sedangkan hasil uji Chi-Square juga menunjukkan bahwa lama bekerja dengan persepsi tak berhubungan nyata.

\section{Hubungan antara Karakteristik Contoh dengan Konsumsi}

Menurut Darmansyah (1996) terdapat dua faktor yang dapat mempengaruhi kebiasaan konsumsi suplemen yaitu karena individu sadar dan mengetahui fungsi zat gizi yang dikandung suplemen bermanfaat bagi dirinya dan juga karena dipengaruhi persuasi atau tindakan promosi yang mendorong sugesti konsumen untuk mengonsumsi suplemen.

Umur contoh dengan frekuensi dan jumlah konsumsi tidak berhubungan nyata berdasarkan hasil uji Chi-Square ( $p>0.05)$.

Menurut tingkat pendidikan, tidak terdapat hubungan antara pendidikan dengan frekuensi dan jumlah konsumsi ( $p>0.05)$. Pada penelitian ini, pendidikan bukan merupakan suatu ukuran akan terjadinya peningkatan konsumsi minuman berenergi karena penggunaan 
minuman berenergi dilakukan jika diperlukan oleh contoh.

Begitu pula dengan pendapatan, tidak terdapat hubungan antara pendapatan dengan frekuensi dan jumlah konsumsi ( $p>0.05)$. Walaupun semakin tinggi pendapatan belum tentu konsumsinya juga semakin meningkat. Ada kecenderungan contoh yang memiliki pendapatan yang lebih tinggi maka akan mengonsumsi minuman berenergi secara terus menerus.

Lama bekerja seseorang dapat mempengaruhi kebutuhan akan energinya. Berdasarkan hasil uji Chi-Square terdapat hubungan antara lama bekerja dengan frekuensi konsumsi $(p<0.05)$ dan jumlah konsumsi $(p<0.05)$. Hal ini sesuai dengan alasan yang dikemukakan responden bahwa untuk memenuhi kebutuhan energi untuk melakukan aktivitas maka perlu mengonsumsi minuman energi. Semua aktivitas fisik memerlukan energi yaitu, makin berat aktivitas fisiknya maka makin besar pula kebutuhan energinya. Hal ini menunjukkan bahwa contoh yang memiliki jam kerja yang banyak akan mengonsumsi minuman berenergi secara teratur juga.

\section{Hubungan antara Karakteristik Contoh dengan Preferensi}

Hubungan antara umur, tingkat pendidikan, pendapatan serta lama kerja dengan preferensi dianalisis dengan menggunakan uji Chi-Square. Berdasarkan hasil uji Chi-Square, tidak terdapat hubungan antara umur, pendidikan, pendapatan serta lama kerja dengan preferensi. Hal ini disebabkan rata-rata contoh yang memilih atribut mengenai manfaat minuman berenergi merupakan persentase terbesar dibandingkan atribut lainnya.

\section{Hubungan antara Persepsi, Konsumsi dan Preferensi}

\section{Hubungan Persepsi dengan Frekuensi dan J umlah Konsumsi}

Berdasarkan hasil uji Chi-Square, tidak terdapat hubungan antara persepsi dengan frekuensi dan jumlah konsumsi. Walaupun demikian, terdapat kecenderungan bahwa persepsi yang baik dapat meningkatkan konsumsi minuman berenergi contoh.

\section{Hubungan Preferensi dengan Frekuensi dan J umlah Konsumsi}

Berdasarkan hasil analisis, preferensi tidak berhubungan $(p>0.05)$ dengan konsumsi minuman berenergi. Hal ini menunjukkan bahwa preferensi atribut-atribut tertentu tidak selalu membuat konsumen memilih suatu produk yang mempunyai preferensi lebih baik. Namun terdapat atribut yang diutamakan lainnya berdasarkan pilihan konsumen. Menurut Sumarwan (2003), konsumen mengonsumsi produk pangan karena konsumen mengetahui manfaat produk pangan tersebut bagi kesehatan tubuhnya. Konsumen sering kali berpikir mengenai manfaat yang dirasakan jika mengonsumsi atau membeli suatu produk, bukan mengenai atributnya.

\section{KESIMPULAN}

Usia contoh berkisar antara 24 tahun hingga 50 tahun dengan rata-rata 36.5 tahun. Lebih dari separuh contoh (52.8\%) memiliki tingkat pendidikan SMP. Rata-rata pendapatan per bulan adalah Rp $815555,6 \pm 122$ 344,8. Sebagian contoh $(44.4 \%)$ memiliki pendapatan per bulan berkisar antara Rp 680001 hingga Rp 800 000. Sebanyak $86.1 \%$ contoh memiliki jam kerja antara 10 hingga 13 jam per hari. Seluruh contoh dalam keadaan sehat.

Merek minuman berenergi yang dikonsumsi terbanyak secara berurutan adalah merek Extra Joss sebanyak $44.4 \%$ contoh, merek Hemaviton Jreng sebanyak $19.4 \%$ contoh serta merek Kuku Bima Energy sebanyak 13.9\% contoh. Lebih dari dua pertiga contoh (77.8\%) mengonsumsi minuman berenergi dalam bentuk kemasan sachet. Sebagian besar contoh (55.56\%) termasuk ke dalam kategori frekuensi sering (7-14 kali/minggu) mengonsumsi minuman berenergi. Rata-rata jumlah konsumsi minuman berenergi per minggu yaitu 9.72 uks/ minggu. Sebanyak $66.67 \%$ contoh termasuk dalam kategori rendah jumlah konsumsinya.

Mayoritas contoh $(88.9 \%)$ merasakan secara langsung badannya terasa segar. Manfaat badan terasa berenergi dirasakan juga hampir seluruh contoh (91.7\%). Sebagian besar contoh (72.2\%) memiliki persepsi yang baik terhadap manfaat mengonsumsi minuman berenergi.

Atribut pada minuman berenergi yang dianggap sangat penting oleh contoh adalah manfaat penambah energi dan manfaat pemulih tenaga. Atribut yang dianggap biasa oleh contoh adalah atribut harga. Sebanyak $72.2 \%$ contoh termasuk dalam preferensi kategori sedang.

Analisis hubungan antara karakteristik contoh dengan persepsi dan preferensi menunjukkan tidak terdapat hubungan nyata. Sementara itu terdapat hubungan nyata antara karakteristik contoh yaitu lama kerja dengan 
konsumsi. Tidak terdapat hubungan yang nyata antara persepsi, konsumsi dan preferensi.

Hasil analisis kandungan energi pada ketiga sampel secara berurutan (Ekstra Joss, Hemaviton Jeng dan Kuku Bima Energy) adalah $4.278 \mathrm{Kal} / \mathrm{gram}, 2.599 \mathrm{Kal} / \mathrm{gram}$ dan 2.720 $\mathrm{Kal} / \mathrm{gram}$. Hasil analisis kandungan kafein secara berurutan adalah $8778 \mathrm{mg} / \mathrm{kg}, 9252 \mathrm{mg} /$ $\mathrm{kg}$ dan $7688 \mathrm{mg} / \mathrm{kg}$.

\section{DAFTAR PUSTAKA}

Almatsier S. 2003. Prinsip-Prinsip Imu Gizi. Gramedia, Jakarta.

Assael H. 1992. Consumer Behavior and Marketing. Action, Boston.

BPOM. 1996. Ketentuan pokok pengawasan suplemen. http://www.bpom.go.id

Darmansyah. 1996. Pendapat para pakar terhadap suplemen. Majalah Warta Konsumen. Februari, hlm 9-13.

Engel JF, Blackwell RD, \& Miniard PW. 1994. Perilaku Konsumen. (Budiyanto FX, penerjemah), Consumer Behavior. Binarupa Aksara, Jakarta.

Gaman PM \& Sherington KB. 1990. Nutrition in Practice. Dalam Gaman PM \& Sherington KB (Eds.), The Science of Food (3 $3^{\text {rd }}$ edition). Pergamon Press, New York.

Groff JL \& Gropper SS. 2005. Advanced Nutrition and Human Metabolism ( $3^{\text {rd }}$ Edition). Wadsworth Thomson, Australia.

Hariyanto. 2001. Persepsi, Sikap, dan Perilaku Masyarakat Terhadap Air Sungai. Disertasi Doktor. Sekolah Pasca Sarjana, Institut Pertanian Bogor.

Hidayat B. 2002. Teknik Formulasi Minuman Olahraga untuk Mempertahankan Stamina Atlet. http://www.kompascyber.com [13 Agustus 2007]

Kanarek RB \& Kaufman RM. 1991. Nutrition and Behavior: New prespectives. Van Nostrand Reinhold, New York.

Kardes FR. 2002. Consumer Behavior and Managerial Decision Making ( $2^{\text {nd }}$ Edition). Prentice-Hall of India Private Limited, New Delhi.
Khomsan A. 2004. Peranan Pangan dan Gizi untuk Kualitas Hidup. Gramedia Pustaka Utama, Jakarta.

Khumaidi M. 1994. Bahan Pengajaran Gizi Masyarakat. BPK Gunung Mulia, Jakarta.

Marlinda I. 2001. Bahaya Minuman Berenergi. http://www.intisari.net [30 November 2006]

Nielsen SS. 1998. Food Analysis (2 ${ }^{\text {nd }}$ Edition). Aspen Publication, Maryland.

Peraturan Pemerintah Republik Indonesia Nomor 69 Tahun 1999 tentang Label dan Iklan Pangan. http://www.unsrat.ac.id/ hukum/pp/pp_69_99.htm. [22 September 2007].

Sampoerno \& Fardiaz D. 2001. Kebijakan dan Pengembangan Pangan Fungsional dan Suplemen Indonesia. Dalam Nuraida L \& Hariyadi RD (Eds.), Proceeding Seminar Nasional Pangan Tradisional sebagai Basis Industri Pangan Fungsional dan Suplemen (hlm. 1-13). Pusat Kajian Makanan Tradisional, Institut Pertanian Bogor.

Siregar. 2005. Benarkah minuman berenergi selalu berenergi? http://www.gizi.net [7 Agustus 2007]

Slamet Y. 1993. Analisis Kuantitatif untuk Data Sosial. Dabora Publisher, Solo.

Suhardjo \& Kusharto CM. 1987. Prinsip-Prinsip Ilmu Gizi. Kanisius, Jakarta.

Sumarwan U. 2003. Perilaku Konsumen Teori dan Penerapannya dalam Pemasaran. Ghalia Indonesia, Jakarta.

Sunarti E et al. 1990. Aktivitas kerja dan tingkat konsumsi energi serta zat gizi Pegawai Negeri Sipil di lingkungan lembaga penelitian IPB. Laporan penelitian. Fakultas Politeknik Pertanian, IPB.

Syah D \& Utama S. 2005. Manfaat dan Bahaya Bahan Tambahan Pangan. Fakultas Teknologi Pertanian, IPB, Bogor

Wikipedia. 2006. Minuman Berenergi. http:// wikipediafreedictionary.com [12 Desember 2006]. 
Jurnal Gizi dan Pangan, November 2007 2(3): 13 - 25 